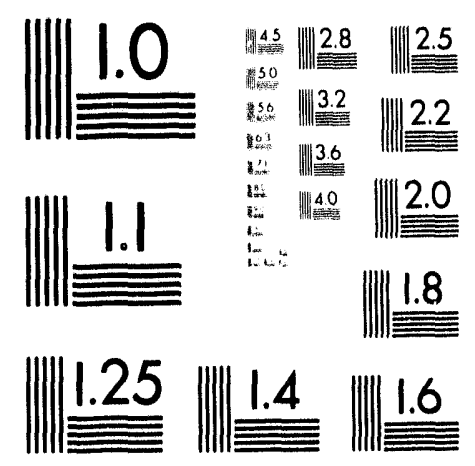



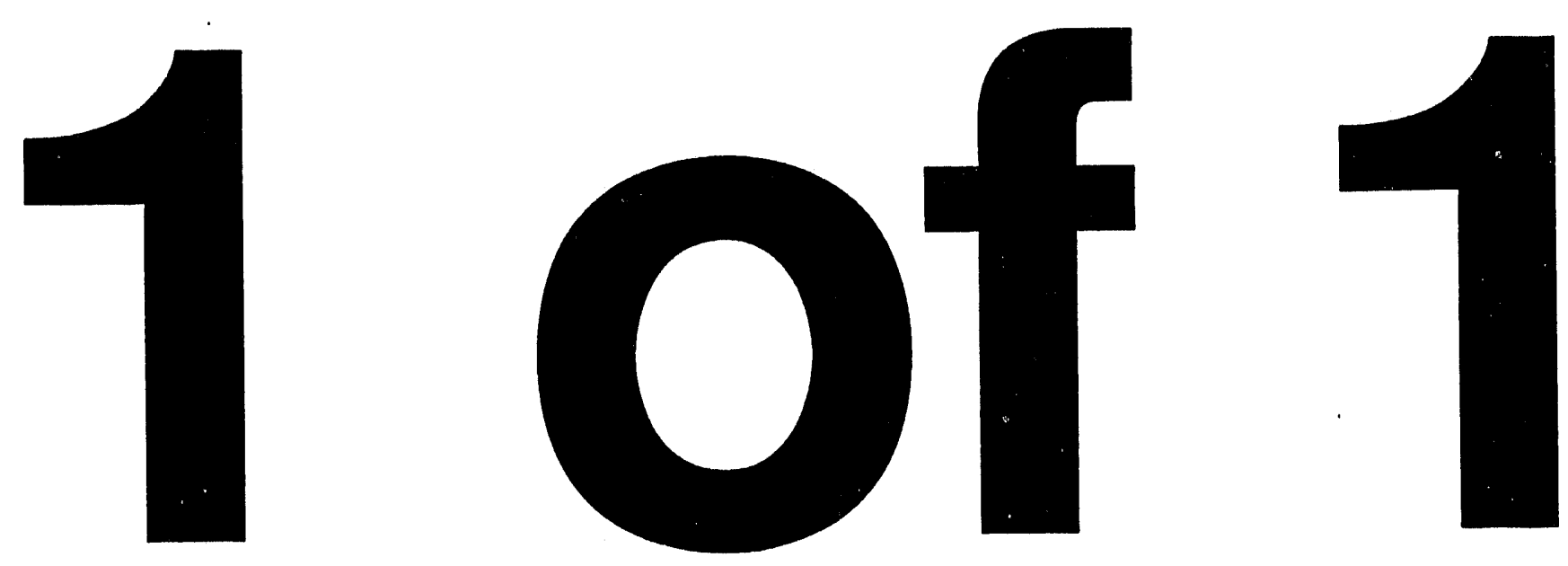
DOE Grant No. DE-FG05-89ER14061, Amendment AO02

\author{
PROGRESS REPORT \\ 1 September 1991 - 31 August 1993 \\ BOARD ON EARTH SCIENCES AND RESOURCES \\ COMMITTEE ON SEISMOLOGY \\ U.S. GEODYNAMICS COMMITTEE \\ COMMITTEE ON GEODESY \\ GEOPHYSICS STUDY COMMITTEE
}

\title{
BOARD ON EARTH SCIENCES AND RESOURCES
}

Recent Reports

- Solid-Earth Sciences and Society (February 1993)

Breakthroughs in scientific understanding during the past quarter century as well as innovative technologies for gathering and organizing large amounts of information are expanding the frontiers of knowledge in the earth sciences at an accelerating pace. Basic research has increased our understanding of the origin and internal workings of our planet, of the processes that modify our landscape, and of the evolution of life during times of quite different global environments. A new approach to studying earth processes, in which the earth is viewed as an integrated, dynamic system rather than a collection of isolated components, has emerged.

The report explores these important new directions in earth sciences research and examines how they can enhance society's ability to make wise decisions on resource development, waste disposal, environmental protection, natural hazards reduction, and land use. The report, which reflects a long-term effort by a diverse expert committee, presents a vision of this rapidly changing field: its scope and goals, its emerging research issues, and its scientific contributions and applications.

As enunciated in this report, Solid-Earth Sciences and Society, the challenge to the earth science community is to develop an integrated approach to the solid earth and its resources. Worldwide improved living standards and population increases combine to pose new problems extending from basic issues of the physics and chemistry of the earth to complex considerations of resources, environment, and land utilization. We have reached a critical time in the solid-earth sciences. Many in the professional community are shifting their focus from exploring for and developing resources to addressing environmental and social problems on global as well as regional scales. Others are working to maintain the research base and acquire the new knowledge upon which the applications are built. The report recommends priorities for future research and discusses the scientific challenges facing our society.

- The Mapping Science Committee issued a report, Toward a Coordinated Spatial Data Infrastructure for the Nation (March 1993), which addresses the accessibility, communication, and use of spatially referenced data to support a wide variety of decisions at all levels of society. By creating an effective, efficient, and widely accessible "information highway" - the backbone of a robust National Spatial Data Infrastructure (NSDI) - data could be readily transported and easily integrated both 
horizontally (e.g., across environmental, economic, and institutional data bases) and vertically (e.g., from local to national and eventually to global levels). The NSDI could provide transparent access to myriad data bases for countless applications (e.g., facility management, real estate transactions, taxation, land-use planning, transportation, emergency services, environmental assessment and monitoring, and research). This report was preceded by two others. Spatial Data Needs: The Future of the National Mapping Program (1990), examined the digital spatial data required by a broad spectrum of users for the application of geographic information systems and the degree to which programs of the National Mapping Division (NMD) of the USGS fulfilled those needs. The other report, Research and Development in the National Mapping Division (USGS): Trends and Prospects (1991) assessed the directions of $R \& D$ in the National Mapping Division.

- The Committee on Geophysical and Environmental Data, which has played a national role for over 20 years, is currently completing several of its occasional requested reviews (involving site visitation) of elements of World Data Center $A$ that are housed in federal data centers. The Committee also completed a report, A U.S. Strategy for Global Change Data and Information Management (1992), at the request of the Committee on Earth and Environmental Sciences. The committee also convened a forum to comment on the federal plan for global change data management; the results of the forum are reported in 1992 Data Forum: A Review of a Federal Plan for Managing Global Change Data and Information. A similar forum has been requested to review the plans for federal implementation of this plan in 1993.

- The Board, in a cooperative activity with the Ocean Studies Board, completed A Review of the Long-Range Plan of the Ocean Drilling Program (1992).

\section{On-Going Board Studies}

Mapping Science Committee

- Nautical Charting. At the request of the National Oceanic and Atmospheric Administration, a study is assessing the information content, the user needs, and the revision cycle of the nautical chart series and the transition from paper map to digital data bases. This is a joint activity with the NRC Marine Board. The study should be complete in 1994.

- National Spatial Data Infrastructure: Base Data. The study should be complete in 1993.

- National Spatial Data Infrastructure: The Role of States and Partnerships. The study should be complete in 1993.

U.S. Geodynamics Committee

- Geomagnetic Initiative. The study is an assessment of the status of geomagnetic research and examines the benefits of coordinated activities, particularly between operational and research needs. A workshop was held in 1992, and the report will be issued in 1993. 
- Decade Volcano. The study will examine the research needs for the U.S. volcanoes designated as "Decade Volcanoes" by the International Decade for Natural Disaster Reduction. A workshop on Mount Rainier was held in September 1992; a report will be issued in 1993.

\section{Committee on Geodesy}

- Airborne Geophysics. The study will assess the enhanced capabilities of geophysical and photogrammetric measurements from aircraft having precise locational control using GPS. A workshop is planned for the summer of 1993.

\section{Committee on Seismology}

- Strong Ground Motion. A study will develop a framework for a plan for the nation's strong-motion program. Such a plan is needed in view of the current lack of coordination among those who install instruments, and collect, analyze, archive, and disseminate the data; the various types of users; and the policy makers for the program. A panel is about to be appointed and will operate for an 18-month period.

- Probabilistic Seismic Hazard Evaluation The study, which was requested by the Nuclear Regulatory Commission, will evaluate the methodology proposed for reconciling the results of two earlier studies of probabilistic seismic hazards at nuclear powerplanits. The evaluation will be a 24-month effort with a short report to the Nuclear Regulatory Commission.

Committee on Geophysical and Environmental Data

- 1993 Data Forum. The committee has been requested by the Interagency Coordinating Committee on Data Management for Global Change to convene a forum to comment on the implementation plan of the federal program.

- Review of the National Snow and Ice Data Center

- Review of the National Oceanic Data Center

- Review of the National Space Science Data Center

Committee on Advanced Drilling Technologies

The study that will examine opportunities for advances in the fundamental technologies applicable to the drilling and breaking of rock. The study will consider the scope and direction for research needed to realize these opportunities. This activity is joint with the NRC Geotechnical Board. A report should be completed by the end of 1993 or early in 1994.

\section{Committee on Alaska Outer Continental Shelf}

The study is evaluating the environmental issues and the resource potential of possible lease sales by the Minerals Management Service of tracts on the Alaskan Outer Continental Shelf. This is a joint study with the NRC Board on Environmental Studies and Toxicology. The report will be completed in 1993. 
Geophysicss Study Committee

- Global Surficial Fluxes. The study is designed to report on the state of knowledge of the major fluxes and pathways by which materials are transferred from one site to another on the surface of the Earth. The study will be complete in 1993.

- Effects of Past Global Change on Life. The study addresses major transitions from one set of environmental conditions to another and evaluates the impacts of such changes on the biosphere. These changes have entailed not only extinction, but also shifts in the distribution and abundance of species and origins of new species in response to opening of new environmental opportunities.

\section{Committee on Earth Resources}

The committee provides input to the board on a variety of possible specific studies needed in the areas of resource availability, resource assessment, and environmentally sound resource exploitation on public and private lands. The committee has recommended that the Board pursue several initiatives relating to national resource policy.

\section{Committee on Rediscovering Geography}

The committee will undertake a critical assessment of the directions and challenges for the science of geography, particularly in light of emerging societal expectations, educational thrusts, and its use in decision making. The activity has been approved through the NRC; committee membership and funding are currently being addressed. This will be a 24-month effort.

\section{Possible New Activities}

The BESR expects to consider several topics that could be initiated as separately funded studies in the coming year. Included among these possible topics are:

- Undergraduate education in the earth sciences is linked to a recurring problem of the solid-earth science profession: the swings in employment that repeatedly led to episodes of underemployment interspersed with episodes of intense demand. There is some perception that with the movement of the dominant levels of employment away from the extractive industries and into the more environmentally concerned fields of hydrogeology, engineering geology, and urban geology, the intensity of swings in employment is becoming dampened, but similar optimistic views have been proved wrong in the past. The Board is ready to take under review the whole issue of the long-term relationship between content, location, and style of research, and education programs and employment within the solid-earth science community.

- The degree to which earth scientists can characterize the upper kilometer or so of the Earth's crust and the extent of our understanding of the dominant processes in the shallow crust. The kind of study under consideration has important applications for improved oil and gas exploration and production, for understanding mineral distribution, and waste disposal and cleanup activities. 
- Several resource initiatives, including an analysis of the availability of industrial mineral resources needed to rebuild the nation's infrastructure, are being considered by the BESR.

- Continuation of the "Summit Meeting" of Professional Earth Science Society Presidents. The May 1991 summit was attended by society presidents and executive directors for over 15 earth science sncieties. From that meeting, a series of resolutions was prepared (see September 1991 issue of Geotimes); in addition, an ad hoc committee was formed to address earth science in $K-12$ education. A consensus was reached that the societies should coordinate their educational activities to avoid duplication and achieve maximum impact. A similar summit is projected for 1993.

- The Mapping Science Committee expects to undertake a study on application of information technology to environmental problem solving in developing countries. This activity would be joint with the NRC Board on Science and Technology in International Development and potentially sponsored by U.S. AID and the World Bank.

- Requests for BESR studies/activities by federal agencies. The BESR will continue to be responsive to federal agency requests for studies on specific issues.

\section{Membership of the Board on Earth Sciences and Resources}

WILLIAM L. FISHER, Texas Bureau of Economic Geology, Chairman

SAMUEL S. ADAMS, minerals consultant, New Hampshire

GAIL M. ASHLEY, Rutgers University, New Jersey

MARK P. CLOOS, University of Texas, Austin

NEVILLE G.W. COOK, University of California, Berkeley

JOEL DARMSTADTER, Resources for the Future

DONALD J. DEPAOLO, University of California, Berkeley

GORDON P. EATON, Lamont-Doherty Geological Observatory, New York

W. GARY ERNST, Stanford University

NORMAN H. FOSTER, Independent Petroleum Geologist, Denver

FREEMAN GILBERT, University of California, San Diego

DONALD C. HANEY, Kentucky Geological Survey

THOMAS H. JORDAN, Massachusetts Institute of Technology

ANDREW H. KNOLL, Harvard University

PHILIP E. LAMOREAUX, P.E. LaMoreaux and Associates, Inc.

SUSAN LANDON, Thomasson Partner Associates, Denver

J. BERNARD MINSTER, Scripps Institution of Oceanography

CAREL OTTE, NAE, Unocal Corporation (retired)

JILL D. PASTERIS, Washington University

FRANK M. RICHTER, University of Chicago 


\section{COMMITTEE ON SEISMOLOGY}

\section{RECENT ACTIVITIES}

During the past year, working groups of the committee have reviewed and reported on the status of regional networks, and wrote a report on the real-time warning of earthquakes. [A critical review of the field as a whole is incorporated into a review of the solid-earth sciences.] A report on the status of seismology is being considered in the future.

Recent activities of the Committee on Seismology include:

1. developing plans for a workshop to plan for storing and archiving strong motion data and to foster greater interchange between seismologists and engineers;

2. establishing a panel to advise on probabilistic seismic hazard estimates.

\section{PROPOSED ACTIVITIES}

The field of seismology is going through revolutionary changes with new measurement capabilities, new analytical capabilities, and new understanding of earthquake processes at hand are still evolving. Earthquake "gaps" are recognized as diagnostic elements for focusing on future large earthquakes; regional and national networks are under intense study, and future directions for them are emerging; and large scientific projects are under way in seismology which will bring new insights into earth structure, wave propagation, and earthquake processes. Ground motions and recurrence rates of earthquakes are major factors in the assessment of earthquake hazards, and improvements in both factors are badly needed. Of particular concern to seismologists is the outlook for the exploration industry, which hires about 75 percent of seismologists graduating from universities. Less exploration effort in the United States is having a substantial effect in decreasing the undergraduate enrollment.

The following topics are proposed, as either continuing or new projects:

\section{Studies, Preparation, and Publication of Reperts}

a. The Committee on Seismology will continue to review progress and needs for research on strong ground motions. In 1987 the Committee on Seismology and the Committee on Earthquake Engineering published a joint study of strong ground motion programs. The Committee on Seismology will form a joint panel of seismologists and engineers to develop a plan for managing and archiving strong motion data.

b. Review the methodologies used in estimating seismic hazards at nuclear reactor sites.

c. In cooperation with the Board on Mathematical Sciences, sponsor a meeting on high technology computing. 
d. The Committee on Seismology assesses on a continuing basis the health and outlook for seismology. Several factors are of current concern to the committee, such as national funding for research, decreased exploration for petroleum and mineral resources, the balance of student population, and the outlook for new hires.

Seismology is burgeoning with opportunities. New and powerful analytical techniques have been developed for inversion of earthquake time and velocity data, and new data sets are becoming available for analysis in terms of earth structure and earthquake processes. These create new opportunities for research on problems related to earth structure, earthquake processes, and utilization of data to warn the populace in real time of earthquake hazards or to forecast impending events.

\section{A Continuing Leok at the Operations and Supvert of the U.S. Government-Supported} Notworks

The Committee on Seismology has had a continuing responsibility to provide scientific and technical advice regarding the operation of the Worldwide Standardized Seismograph Network. Originally, the committee selected the instruments and observatory sites on a worldwide basis. The support of this network is beginning to stabilize and improvements to it are in process (both of which were recommended by the committee). However, the network is generally regarded as being underfunded and is likely to remain so in the near future.

Seismology is in a new era; new digital data bases are being used for national and worldwide networks. Upgraded Worldwide Standardized Seismograph Network stations will be augmented by stations designed for research purposes to provide this new digital data base. Research capabilities will be greatly improved both by a global digital network and a national digital network, but obtaining adequate funds is a continuing problem that requires the continued attention of the committee. Of particular concern is the outlook for regional networks for which a satisfactory solution to long-term funding for both network operations and research is needed. This problem, addressed in the recently published "Assessing the Nation's Earthquakes," is of continuing concern to the committee.

\section{Membership of the Committee on Seismology}

THOMAS H. JORDAN, Massachusetts Institute of Technology, Chairman

WALTER J. ARABASZ, University of Utah

KEVIN J. COPPERSMITH, Geomatrix Consultants

F. A. DAHLEN, Princeton University

STEVEN M. DAY, San Diego State University

THOMAS C. HANKS, U.S. Geological Survey, Menlo Park

CHARLES A. LANGSTON, Pennsylvania State University

THORNE LAY, University of California, Santa Cruz

DONALD L. PAUL, Chevron Oil Field Research Company

JAMES R. RICE, Harvard University

ANN M. TREHU, Oregon State University 


\section{U.S. GEODYNAMICS COMMITTEE}

\section{MOST RECENT ACTIVITY}

In 1992, the USGC convened two topical workshops: (1) on a geomagnetic initiative, and (2) on establishing a research agenda for studies at Mount Rainier for the Decade Volcano project of the International Decade of Natural Disaster Reduction (IDNDR).

Geomagnetic Research. Belioving that there are significant research opportunities in geomagnetic research not fully exploited, the USGC designated this as one of its priority topics several years ago. The USGC appointed a Task Group to develop recommendations for the committee; they reviewed the topic broadly and recommended that the USGC convene a workshop:

- to address challenges and future directions in geomagnetic research and applications;

- to consider the needs for an ongoing mechanism for future discussions and interaction, coordination, etc.; and

- to develop a plan of action.

A workshop on the national geomagnetic initiative was held in March 1992. The workshup addressed challenges and future directions in geomagnetic studies, including all aspects of the temporal and spatial variations, from the near-earth space environment to the earth's core; considered the needs for an ongoing mechanism for future interaction and coordination; and developed a plan of action. It also considered a plan for a national, longterm program to systematically characterize the spatial and temporal behavior of the earth's magnetic field on local, regional and global scales by satellite, aircraft, ship, and surface measurements.

Participation in the workshop was sufficiently large to cover the range of topics and need for diverse representation, small enough for effective communication, and reflected the five major scientific topics identified for the workshop; relevant current and planned national and international programs; recommendations of pertinent National Academy of Sciences-National Research Council bodies, especially the Space Studies Board, Committee on Solar-Terrestrial Research, and Board on Earth Sciences and Resources; recommendations of interested national scientific societies, especially the American Geophysical Union; and recommendations of the federal agencies. A final report will be issued by the U.S. Geodynamics Committee as a result of this workshop.

Decade Volcano: Research Agenda for Mount Rainier. The committee convened a workshop (18-20 September 1992) that focused on coordinated geological, geochemical, and geophysical studies of Mount Rainier, which is one of the two U.S. Decade Volcanoes. The aim was to identify new approaches to volcano studies-including (1) monitoring and (2) identifying what data are needed to learn more about how volcanoes work. The goal is to develop better volcano science and to apply what we learn to improve assessment of hazards at volcanoes both in the United States and elsewhere. 
A Decade Volcano is a volcano selected to be the subject of intensive, integrated, multidisciplinary and multinational cooperative research on the entire range of activities needed in volcanic hazards mitigation. Internetional Association of Volcanology and Chemistry of the Earth's Interior (IAVCEI) adopted the Decade Volcano Project as one of its major activities for the IDNDR. A Decade Volcano has the following characteristics:

- Representative of one or more of the major volcanic hazards;

- Geologically active with a chance for activity during the IDNDR;

- In a populated area;

- Not thoroughly studied, yet not totally unknown; and

- Situated in a country that can either benefit from training or can provide training for scientists from developing countries.

Activities at Decade Volcanoes should include:

- Estaulishment of state-of-the-art monitoring and mapping techniques;

- Research on how eruptions impact man and the local environment;

- Development of emergency plans, warning systems, and practice drills by civil defense and community leaders; and

- Development of appropriate engineering countermeasures for mitigating adverse effects of volcanic activity.

During 1993, the USGC will issue formal reports originating from the above two workshops. The committee met in December 1992 at the AGU in San Francisco and will meet during the late spring of 1993 in Washington, D.C. The USGC will continue to consider topics such as the international component of continental scientific drilling, seismic reflection profiling, and a suite of both technique and observational related activities.

\section{Membership of the U.S. Geodynamics Committee}

ROBIN BRETT, U.S. Geological Survey, Chairman

DON L. ANDERSON. California Institute of Technology

WILLIAM DICKINSON, University of Arizona

RICHARD S. FISKE, National Museum of Natural History

T. MARK HARRISON, University of California, Los Angeles

RAYMOND JEANLOZ, University of California, Berkeley

KENNETH LARNER, Western Geophysics Company

ELIZABETH MILLER, Stanford University

JOHN C. MUTTER, Lamont-Doherty Geological Observatory

ROBERT S. YEATS, Oregon State University

\section{Ex-officio}

KEVIN C. BURKE, University of Houston (President, Inter-Union Commission on the Lithosphere) 


\section{COMMITTEE ON GEODESY}

In the past year, the committee began to investigate the applications of airborne techniques that would not be possible in the absence of precise GPS navigation. The range of topics is rich enough to warrant a special study, with input from the various agencies actively involved in airborne surveys and geophysical and geodetic measurements. The committee will conduct a study this year, starting with a dedicated workshop and concluding with a report that will emphasize new geoscience applications made possible by modern geodetic tools.

During the coming year the committee will focus on the following broad topics, which represent both new and continuing issues resulting from extensive discussions between committee members and agency liaison representatives:

\section{Declassification of geophysical and geodetic data}

The issue of declassification of geophysical and geodetic data had been discussed by the committee in 1991. A "white paper" was prepared, outlining the rationale for further declassification of GEOSAT data in the southern hemisphere. This white paper was communicated to NAS president, Dr. Frank Press. The issue was also introduced in the context of a round table discussion of priority data needs, organized by Senator Al Gore.

The committee will coordinate its activities on the declassification issue with the liaison members of the appropriate agencies, particularly NOAA, NASA, and USGS. The committee will also continue to coordinate its efforts with the American Geophysical Union (AGU) and other relevant NAS groups, such as the Committee on Geophysical and Environmental Data and the Navy Review Panel of the Ocean Studies Board. The committee was recently informed that AGU activities in this arena have ceased, and it is hoped that the relevant NRC committees can continue efforts on this topic. The committee proposes to pursue an exchange of information and views with these groups and to explore the possibility of coordinating efforts to identify data sets for declassification.

\section{SA/AS \& GPS geodesy}

The Global Positioning System (GPS) will be the dominant space geodetic system used by all geodesists in the coming decade. The DOD has a stated policy that Selective Availability (SA) and Antispoofing (AS) will be implemented. This policy entails a definite cost to the practicing geodesists and to the surveying community. At a past meeting of the Committee on Geodesy. Dr. Thomas Herring presented a methodology to evaluate the true cost of implementing SA/AS, as incurred by the geodetic/surveying community. In addition, various issues concerning the transition to GPS in the surveying community were raised. The committee proposes to continue an evaluation of the impact of SA/AS on the geodetic community. The Navy Review Panel of the Oceans Studies Board has stated its interest in such issues, and Dr. Herring is prepared to brief them at a future meeting. 


\section{Alrborne geodesy/geophysics}

Although space geodetic techniques have dominated the scene in recent vears. the committee recognizes that airborne techniques historically have played a very important role in geodesy. These techniques range from photogrammetry to airborne gravimetiv With the advent of GPS and the possibility of having very precise navigation, new scientific opportunities, such as repeated high precision surveys including both potential field measurements and precise altimetry, or ultra-precise (centimeter level) photogrammetry, exist. Airborne techniques may play an important role in future research. The committee has initiated a study 10 assess the promise of such techniques 10 support regional geodesy, from surveying applications to the measurement of global warming indicators, such as glacier and ice sheet mass balance. It will coordinate this assessmanti with other interested communities. such as the volcanological community and the polat sciences community. As a part of this study, the committee will host an agency sponsored workshop on airborne geoscience, which is being separatoly lunded

\section{Miscellaneous}

Of special concern to the committee is the possibility that no near earth geopotential mission will be flown before the next century. For a variety of reasons, geopotantial missions discussed as early as a decade ago (e.0.. GRM. ARISTOTELES) have all mat with major budgetary difficulties. The committee is concerned with the potentially megative impact on the earth sciences, not only because the Earth's gravity and magnotic lieide will remain understudied, but also because the full benefit of existing of planned missions $10 \mathrm{~g}$. TOPEX/Poseidon) inay not be realized without improved knowledge of the geopotential. The committee intends to examine this issue carefully and will saek help of other NRC committees, such as the Space Studies and Ocean Studies Boards.

Another issue that the committee plans to examine carefully is the rapidly changing role of agencies involved in geodetic activities. This change reflects the rapid growth of space geodesy and the renewed awareness among the scientific community of the potentially valuable role geodesy can play in global studies of the Earth's internal structure. its evolution, and the environment. In this sense, the traditional roles played by some agencies (e.g., the National Geodetic Survey) may need to be rethought. The commitlea endeavors to provide advice on federal programs in reframing the contribution of geodesy to agency missions.

The Committee on Geodesy will continue to explore the role of laser ranging instruments. such as the GLAS facility instrument of the FOS mission as well as a possible airborne version that might incorporate aspects of the original GRLS concept. It will also continue discussions of geodesy education, which has been impacted substantially by the advent of GPS. To this effect, members have been urged to comment on a draft revision of the American Geophysical Union booklet, Careers in Geodesy. The Committee on Geodesy looks forward to developing future activities in these areas. 
Membership of the Committee on Geodesy

JEAN-BERNARD MINSTER, Scripps Instisution of Oceanography, Chairman

ROBIN E. BELL, Lamont-Doherty Geological Observatory

B. CLARK BURCHFIEL, Massachusetts Institute of Technology

M. ELIZABETH CANNON, University of Calgary

THOMAS HERRING, Massachusetts Institute of Technology

CHRISTOPHER JEKELI, Phillips Laboratory (AFSC)

ROGER L. MERRELL, Applied Research Laboratories

RICHARD SAil.OR. The Analytic Sciences Corporation

DAVID SANDWELL, Scripps Institution of Oceanography

WILLIAM YOUNG, Riverside County Flood Control \& Water Conservation District, California 


\section{GEOPHYSICS STUDY COMMITTEE Studies in Goophysics}

PLANS FOR 1993

Completion of the studies on:

- Global Surficial Geofluxes: Modern to Glacial

- The Effects of Past Global Change on Life

The modular pattern for the Studies in Geophysics was designed to permit selection of the most timely topics and rapid completion of individual studies to meet the following objectives:

(1) to set forth the current and prospective contributions that the geophysical sciences can make to such concerns of mankind as energy, nonrenewable resources, and the environment;

(2) to provide government officials with technological and scientific evaluations that can help serve as a basis for decision making in matters involving geophysical research and knowledge, both in policies and programs;

(3) to provide to the scientific community itself a basis for judgments with respect to the development of the science of geophysics in the broad sense and with respect to the relative importance to society of the developments within various branches of geophysics.

\section{SELECTION OF STUDIES}

In making its decisions regarding initiation of studies, the GSC follows an established pattern (which takes into account the practical fact that normally only two or three studies can be initiated each year). Suggestions for the selection of new study topics are reviewed by the Geophysics Study Committee in light of the following considerations:

(1) the relative sense of importance and timeliness as indicated by GSC, and by representatives of the federal agencies during GSC meetings and subsequent consultation;

(2) reaction regarding importance and timeliness from the Board on Earth Sciences and Resources and other relevant NAS-NRC committees and boards, and members of the scientific community;

(3) appropriateness of addressing the topic in the format of the Studies in Geophysics; and

(4) identification of an appropriate leading scientist who is enthusiastic about the topic and willing to undertake the necessary leadership of a study as panel chairman. The leadership of the panel chairman is regarded as a findamental element in designing the study and recruiting talented scientists to serve orı the panel. 


\section{REVIEW OF VALUE AND EFFECTIVENESS OF THE STUDIES}

The value and effectiveness of the reports cannot be assessed quantitatively. There are, however, several bases for judgement. Each report has been transmitted to the supporting agencies. Letters from senior officials of these and other agencies are supportive of the view that these reports are perceived to be timely and effective.

The reports are distributed thruugh copies made available to the sponsoring agencies in accordance with their requests (approximately 250-300 copies for each report) and through a complimentary distribution to those U.S. and foreign scientists and officials that are suggested by the panels and GSC. In addition, the reports are more generally available to the public through the National Academy Press; on average, about 2,200 copies of each report have been distributed. This along with published book reviews indicate to the GSC that the reports are considered worthwhile and are being used by the broad scientific community.

The studies involve all areas of geophysics (and some aspects of geology). The group of resulting reports is believed to be of considerable interest as a collection spanning many aspects of geophysics. Several of the individual reports are of interest to a broad spectrum of the geophysical community; others are of primary interest to a particular segment of the geophysical community.

The series of studies can also serve as background documentation for developing research initiatives. Most of the studies can be related to possible elements in the Global Change initiative being developed by the International Council of Scientific Unions. In addition, as illustrative examples, the study Energy and Climate helped to focus scientific and governmental attention on the $\mathrm{CO}_{2}$ (greenhouse) issues in the development of elements in the National Climate Program and in establishing a $\mathrm{CO}_{2}$ program within the Department of Energy; Continental Tectonics provided impetus to the development of the national and international focus on the continental lithosphere; Active Tectonics helped catalyze a program in the NSF Earth Sciences Division long-term plan by the same name. D. Allan Bromley (President Bush's Science Advisor) stated (August 13, 1990, in a letter to Dr. Press) that the Sea-Level Change report is "... an excellent study. It clears up some very real confusion that had plagued some of the IPCC discussions and is the best treatment by far that I have found on this topic."

\section{STUDIES IN PREPARATION}

21. Global Surficial Geofluxes: Modern to Glacial (William W. Hay, Panel Chairman) The study is designed to report on the state of knowledge of the major fluxes and pathways by which materials are transferred from one site to another on the surface of the Earth. The purpose of the study is to (1) present the state of knowledge of modern and late Pleistocene process rates and fluxes, including the last glaciation and during the deglaciation, on a global scale; (2) evaluate the variability inherent in process rates and fluxes in these young geologic times; (3) 
assess the extent to which modern measurements of fluxes already incorporate anthropogenic effects; (4) express variability of natural processes and fluxes in terms of fluctuations and changes occurring on different time scales; (5) identify gaps in the understanding of natural variability of surficial processes and material fluxes; and (6) suggest how the natural variability could be incorporated into the modern processes baselines to be used in models of future change.

Schedule: The report has been reviewed and is in the final stages of preparation. It will be published in 1993.

\section{Qutline}

\section{OVERVIEW AND RECOMMENDATIONS}

\section{BACKGROUND CHAPTERS}

1. Pleistocene-Holocene Fluxes are not the Earth's Norm (William W. Hay)

2. Surficial Weathering Fluxes and Their Geochemical Controls (Abraham Lerman)

3. Global Chemical Weathering on Glacial Time Scales (Lee R. Kump and Richard Alley)

4. Origins and Variable Composition of Present-Day Riverborne Material (Michel Meybeck)

5. Discharge of Fluvial Sediment to the Oceans: Global, Temporal, and Anthropogenic Implications (John D. Milliman)

6. Glacial to Modern Changes in Global River Fluxes (Victor R. Baker)

7. Sediment Fluxes along High Latitude Glaciated Continental Margins, Northeast Canada and Eastern Greenland (John T. Andrews and J. P. M. Syvitski)

8. Late Quaternary Flux of Eolian Dust to the Pelagic Ocean (David K. Rea, Steven A. Hovan, and Thomas R. Janecek)

9. Carbonate and Opal Production in the Ocean (John D. Milliman and Kozo Takahashi)

10. Oceanic Particle Fluxes: Comparisons between Particle Rain Rates and Sediment Burial Rates (Jack Dymond and Mitch Ly/e)

11. Seafloor Diagenetic Fluxes (William R. Martin and Frederick L. Sayles)

22. The Effects of Past Global Change on Life (Steven Stanley, Panel Chairman, James Kennett and Andrew Knoll, co-vice-chairmen)

The recent surge of concern about global change and its impact on the biosphere has engendered interest in research on relevant episodes in the history of the Earth and its biota. The stratigraphic record documents unique events on regional and global scales-events that cannot be duplicated through experiments or observations in the modern world. Through interdisciplinary efforts, we are reconstructing geographic conditions of the past-including climates and properties of ancient oceans - and we are coming to understand the geographic distributions of ancient biotic communities within this framework. Most importantly, we are also identifying major transitions from one set of environmental conditions to another and evaluating the impacts of such changes on the biosphere. These changes have entailed not only extinction, but also shifts in the distribution and abundance of 
species and origins of new species in response to opening of new environmental opportunities.

Schedule: The study panel's symposium and meeting was be held at the October 1990 national meeting of the Geological Society of America. The report should be ready for review in spring 1993 and should be available later this year.

Qutline

\section{OVERVIEW AND RECOMMENDATIONS}

\section{BACKGROUND CHAPTERS}

1. Oxygen and Proterozoic Evolution: An Update (Andrew Knoll and Heinrich Holland)

2. Impact of Late Ordovician Glaciation-Deglaciation on Marine Life (William Berry, $M$. S. Quinby-Hunt, and Pat Wilde)

3. Global Biological Crises Associated vvith Severe Environmental Perturbations in the Cenomanian-Turonian (Cretaceous) Boundary Interval (Erle G. Kauffman)

4. $K / T$ Mass Extinction: Effect of Global Change on Calcareous Microplankton (Gerta Keller and Katharina v. Salis Perch-Nie/sen I

5. Antarctic Marine Biotic Evolution: Relations with Cenozoic Paleoclimatic and Paleoceanographic Change (James Kennett)

6. Tropical Temperature Stability and the Implications for the Distribution of Life (Eric Barron)

7. Neogene Ice Age in the North Atlantic Region: Climatic Changes, Biotic Effects, and Forcing Factors (Steven Stanley and William F. Ruddiman)

8. The Response of Hierarchially-Structured Ecosystems to Long-Term Climatic Change: A Case Study Using Tropical Peat Swamps of Pennsylvanian Age (William DiMichele and Tom Phillips)

9. The Late Cretaceous and Cenozoic History of Vegetation and Climate at Northern and Southern High Latitudes: A Comparison (Rosemary Askin and Robert Spicer)

10. The Impact of Climatic Changes on the Developmerit of the Australian Flora (David C. Christophen

11. Global Climatic Influence on Cenozoic Land Mammal Faunas (S. David Webb and Neil D. Opdyke)

12. Biotic Responses to Temperature and Salinity Changes During Last Deglaciation, Gulf of Mexico (B. P. Flower and James Kennett)

13. Pollen Records of Late Quaternary Vegetation Change: Plant Community Rearrangements and Evolutionary Implications (Thumson Webb III)

14. Climatic Forcing and the Origin of the Human Genus (Steven Stanley)

The committee membership is in the process of being reconstituted.

\section{DISCLAIMER}

\footnotetext{
This report was prepared as an account of work sponsored by an agency of the United States Government. Neither the United States Government nor any agency thsteof, nor any of their employees, makes any warranty, express or implied, or assumes any legal liability or responsibility for the accuracy, completeness, or usefulness of any information, apparatus, product, or process disclosed, or represents that its use would not infringe privately owned rights. Refer. once herein to any specific commercial product, process, or service by trade name, trademark, manufucturer, or otherwise does not necessarily constitute or imply its endorsenient, recom. mendation, or favoring by the United States Government or any agency thereof. The views and opinions of authors expressed herein do not necessarily state or reflect those of the United States Government or any agency thereof.
} 

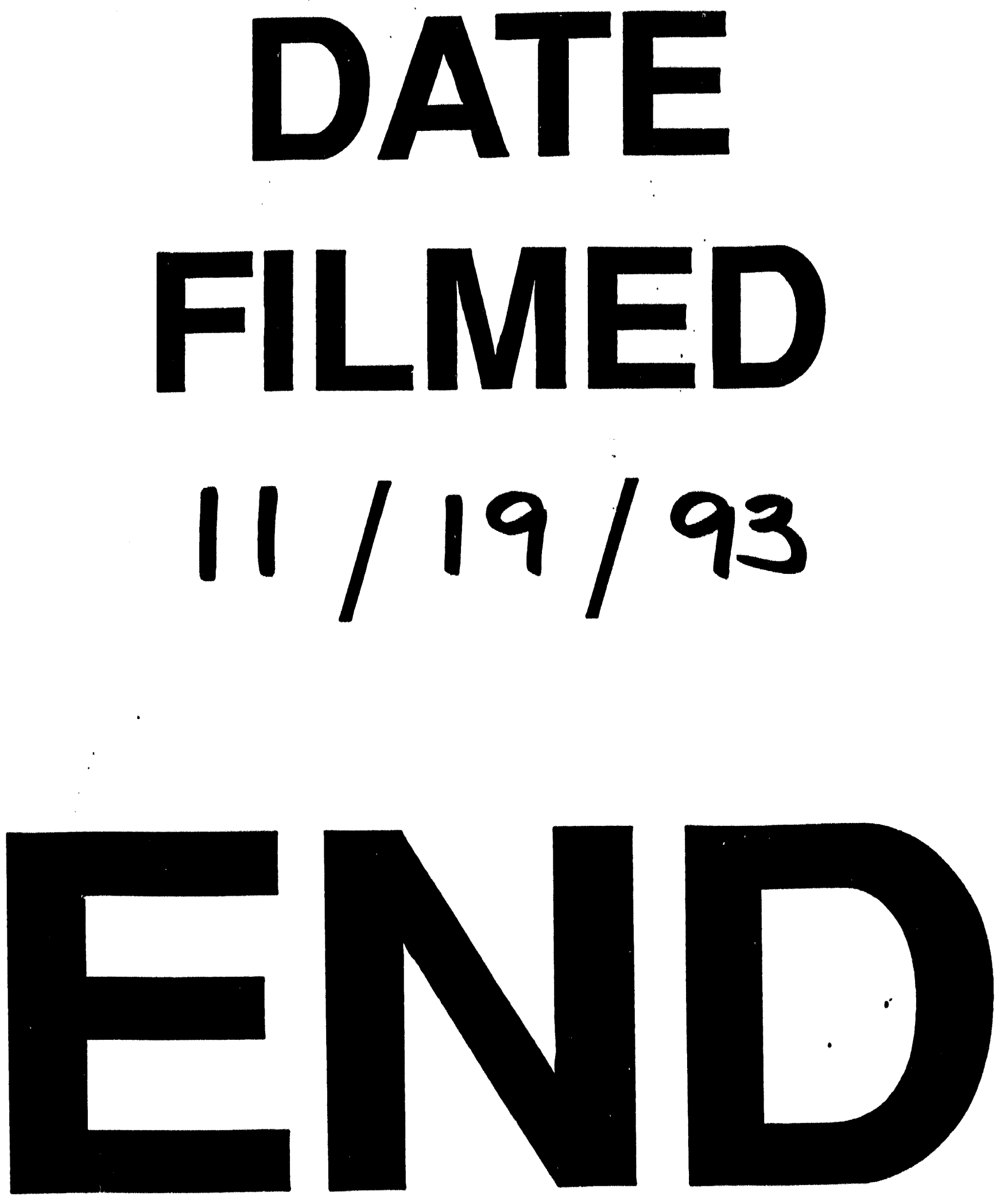
